\title{
Structure of plankton communities in the Dogger Bank area (North Sea) during a stratified situation
}

\author{
Torkel Gissel Nielsen ${ }^{1}$, Bo Løkkegaard ${ }^{2}$, Katherine Richardson ${ }^{3}$, \\ Flemming Bo Pedersen ${ }^{4}$, Lotte Hansen ${ }^{2}$
}

\footnotetext{
${ }^{1}$ National Environmental Research Institute, Department of Marine Ecology and Microbiology, Frederiksborgvej 399 PO Box 358, DK-4000 Roskilde, Denmark

${ }^{2}$ Marine Biological Laboratory, University of Copenhagen, Strandpromenaden 5, DK-3000 Helsinger, Denmark

${ }^{3}$ Danish Institute for Fisheries and Marine Research, Charlottenlund Castle, DK-2920 Charlottenlund, Denmark

${ }^{4}$ Institute of Hydrodynamics and Hydraulic Engineering (ISVA), Technical University of Denmark, Building 115, DK-2800 Lyngby, Denmark
}

\begin{abstract}
Plankton dynamics and hydrography were investigated in the Dogger Bank area, southern North Sea, in May 1990 after the onset of stratification. Greatest phytoplankton biomass and production rates were observed within a subsurface maximum around the pycnocline. At all 51 stations investigated, fluorescence maxima were found at depths $>15 \mathrm{~m}$ and often at depths $>30 \mathrm{~m}$. Small flagellates $(5$ to $7 \mu \mathrm{m}$ ) dominated the phytoplankton. The vertical distributions of the smaller heterotrophs (bacteria, heterotrophic nanoflagellates and ciliates) were closely related to the fluorescence distribution. Carbon budgets established for the southern North Sea suggest that, on and south of the Dogger Bank, ca $15 \%$ of phytoplankton production was channelled directly into the larger zooplankton (copepods), while north of the Dogger Bank, ca $30 \%$ was ingested by copepods. The production of the phytoplankton fraction $>11 \mu \mathrm{m}$ (i.e. potential copepod prey items) could not alone account for the daily carbon demand of the copepods. The carbon budgets suggest that ciliates could potentially have been of nutritional importance to the copepod population. Calculations showed that copepods possessed the ability to clear a substantial fraction of ciliate production. The high biomass of bacteria, heterotrophic flagellates and ciliates, as well as the fact that primary production of the larger (i.e. grazable) phytoplankton did not appear to be sufficient to meet copepod energy requirements, suggest the importance of the microbial loop in carbon cycling in the North Sea during the stratified period.
\end{abstract}

\section{INTRODUCTION}

The North Sea is one of the most investigated marine areas in the world and, due to the region's importance with respect to fisheries, it has the longest known records of fisheries yield. It was on the basis of these data that the North Sea ecosystem model was developed (Steele 1974). The backbone of this model is the assumption that herbivorous copepods are responsible for the transfer of energy both to the higher trophic levels in the pelagial and to the bottom through sedimentation of faecal pellets.

Since 1974, however, our understanding of planktonic ecology has changed significantly and there is now evi- dence that herbivorous copepods may not always be the main vehicle of carbon transfer within the marine food web in the North Sea (e.g. Nielsen \& Richardson 1989). During the last decade, the importance of autotrophic and heterotrophic microorganisms in the planktonic food web has generally been recognized (reviewed by Fenchel 1988). To date, however, few studies have examined the role of these organisms in the food webs of the open North Sea. Nielsen \& Richardson (1989) concluded that the 'microbial loop' was not a significant route for carbon transfer under winter and spring bloom conditions in the open North Sea but suggested, on the basis of biomass ratios of bacteria to phytoplankton, that the microbial loop may be significant during summer. 


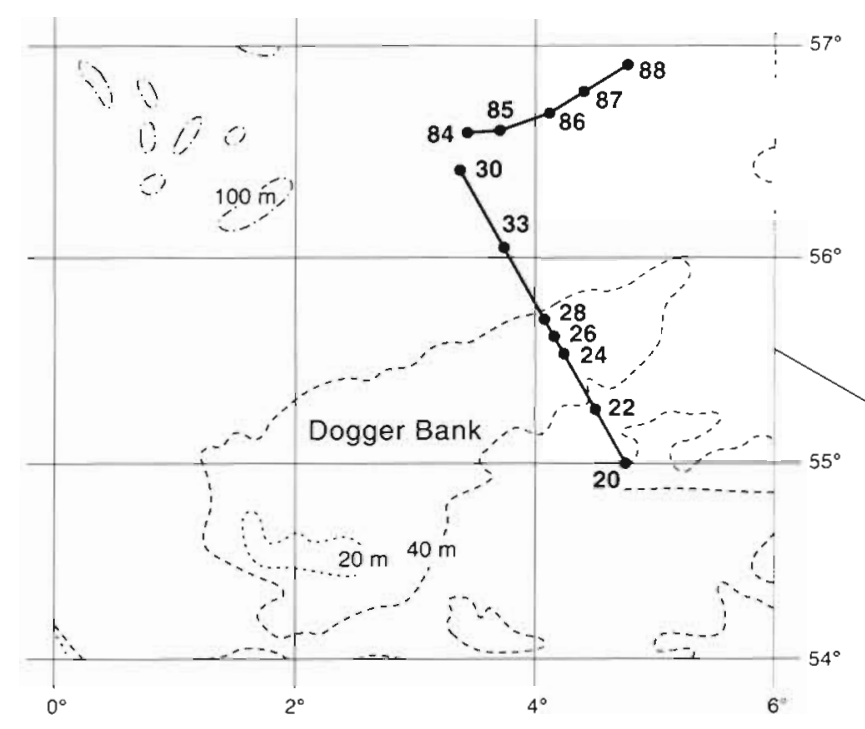

However, no comprehensive studies of the role of microorganisms in the energy transfer in the open North Sea during a non-winter (i.e. stratified) situation have yet been carried out.

As a further development, the important influence that oceanographic features can have on plankton production and on the structure of the food chain in a given area has also been recognized (see review by Cushing 1989).

Large-scale examples of oceanographic discontinuities causing enhanced biological activity are the coastal upwelling systems along the west coasts of Africa (Andrews \& Hutchings 1980) and South America (e.g. Peterson et al. 1988). On a smaller scale, patches of elevated phytoplankton biomass and production are often measured in association with 'fronts' (transition zones between different water masses). Such associations have often been observed in the North Sea and in the neighbouring seas (Holligan et al. 1984: English Channel; Pingree et al. 1978: off Flamborough Head (NE England); Richardson et al. 1985: Irish Sea; Richardson 1985: North Sea/Skagerrak front; Richardson et al. 1986, Kiørboe et al. 1988: Buchan front (off NE Scotland); Nielsen \& Richardson 1989: Dogger Bank). Although fewer studies of copepod production in the North Sea have been carried out, it too has been shown to peak in frontal waters (Kiørboe \& Johansen 1986, Kiørboe et al. 1988).

The Dogger Bank is a shallow region in the southcentral North Sea which is well known for its productive fisheries. From about May until September, the major part of the North Sea is thermally stratified and the transition between thermally stratified and isothermal water lies at or near the Dogger Bank (Pingree \& Griffiths 1978). In view of the many observations of enhanced primary production in frontal regions, it
Fig. 1. Map showing the area investigated and the approximate position of the stations

seems possible that the Dogger Bank region may be more productive than surrounding waters. However, a thorough understanding of plankton dynamics in this part of the North Sea is still lacking. Studies carried out during the winter 1987-88 (K. Richardson, M. R. Heath, D. Baird, A. Christofferson \& D. Seaton unpubl. data) concluded that, because of the shallow depth (average depth ca $25 \mathrm{~m}$ ), primary production at the Dogger Bank is high throughout the winter. This production is the basis for the maintenance of the zooplankton production observed in the southeastern North Sea during winter (Hay et al. 1991). The shallowness of the Bank also causes the spring phytoplankton bloom to be initiated here months before thermal stratification triggers the spring bloom in the northern North Sea (Nielsen \& Richardson 1989).

The purpose of the present investigation was to describe the structure and dynamics of the planktonic community in relation to hydrographic conditions in the Dogger Bank area during summer stratification.

\section{MATERIALS AND METHODS}

Sampling. The study was conducted during a cruise with RV 'Dana' (Danish Fisheries Ministry) from May 25 to June 4, 1990. In all, 51 stations in the southern North Sea were visited. Vertical profiles of temperature, salinity and fluorescence were measured throughout the water column at each station. Additional measurements of biological parameters were carried out at 12 stations (Fig. 1). The present paper focuses on the composition and dynamics of the plankton community along 2 transects: one across the Dogger Bank (Transect 1) and one parallel to the northern edge of the Bank (Transect 2). Each transect was completed within $1 \mathrm{~d}$. 
Temperature and salinity were recorded throughout the water column using a Niel Brown Mark III CTD System. Samples for calibration of the salinity probe were taken at various depths at randomly selected stations. From the CTD and fluorescence profiles, 5 depths were selected so that the surface, pycnocline and bottom water was sampled. Measurements of all parameters and rates were carried out on water originating from the same Niskin water bottle.

Nutrients. Samples for the determination of nutrients $\left(\mathrm{NO}_{2}{ }^{-}, \mathrm{NO}_{3}{ }^{-}\right.$and $\left.\mathrm{PO}_{4}{ }^{3-}\right)$ were measured using an automated nutrient analyzer (Dansk Havteknik) following methods described by Grasshoff (1976). The biological variables measured included chlorophyll a ( $\mathrm{chl}$ a), primary production, and abundance and production of bacteria, autotrophic and heterotrophic nanoflagellates, microzooplankton and copepods.

Chlorophyll a. Chl a fluorescence was measured with a Q-instruments fluorometer (Hundahl \& Holck 1980) mounted on the CTD system. A linear regression was calculated between the fluorescence and chl a from several calibration samples covering the area investigated ( $\mathrm{n}=59, \mathrm{r}^{2}=0.78$ ). This relationship was used in the conversion of the fluorescence profiles to chl a. Chl a analyses were made by filtering water samples onto GF/C filters and immediately extracting the filter in $90 \%$ acetone. The concentration of chl $a$, with correction for phaeopigments, was measured spectrophotometrically following the Lorenzen method (Strickland \& Parsons 1972). The relative size distribution of chl $a$ in the surface water $(2.5 \mathrm{~m})$ was measured fluorometrically. Duplicate samples were filtered on $25 \mathrm{~mm} \mathrm{GF/F,} 3 \mu \mathrm{m}$ Nuclepore and $11 \mu \mathrm{m}$ and $50 \mu \mathrm{m}$ Nitex filters and extracted in $96 \%$ ethanol according to Kiørboe \& Nielsen (1990). The phytoplankton biomass was converted to carbon from the chl a measurements using a conversion factor of 50 (Parsons et al. 1984).

Primary production. Samples for the determination of primary production were taken in the surface and in the fluorescence peak and transferred to $25 \mathrm{ml}$ acidwashed Pyrex bottles. The experimental methods used are described in Nielsen \& Richardson (1989) with the exception that post-incubation filtration was carried out through 11,3 and $0.2 \mu \mathrm{m}$ filters. Light attenuation in the water column was measured using a $Q$ Instrument quantameter. In situ primary production at $1 \mathrm{~m}$ intervals throughout the water column was estimated according to Richardson \& Christoffersen (1991).

Bacteria. The abundance of bacteria was quantified by the acridine orange technique (Hobbie et al. 1977). At least 600 cells were counted on each filter using an Olympus BH-2 epifluorescence microscope. Bacterial volume was calculated from length and width measurements of at least 75 cells per station. The biovolumes were converted to carbon using a conversion factor of
$0.35 \mathrm{pg} \mathrm{C} \mu \mathrm{m}^{-3}$ (Bjørnsen 1986). Bacterial production was measured using 2 methods: incorporation of ${ }^{3} \mathrm{H}$ thymidine (Fuhrman \& Azam 1980) and ${ }^{3} \mathrm{H}$-leucine (Kirchman et al. 1985). Immediately after sampling, triplicate samples $(10 \mathrm{ml})$ were incubated with $5 \mathrm{nM}$ methyl ${ }^{3} \mathrm{H}$-thymidine $\left(20 \mu \mathrm{Ci} \mathrm{nmol}{ }^{-1}\right.$, New England Nuclear) or $10 \mathrm{nM}{ }^{3} \mathrm{H}$-leucine $\left(153 \mu \mathrm{Ci} \mathrm{nmol}{ }^{-1}\right.$, New England $\mathrm{Nu}-$ clear) for $30 \mathrm{~min}$ at in situ temperature $\left( \pm 1^{\circ} \mathrm{C}\right)$. Blanks were prepared by the addition of formalin prior to the addition of the isotope. The incubations were stopped by the addition of buffered formalin ( $1 \%$ final concentration) and samples were filtered onto $0.2 \mu \mathrm{m}$ cellulose nitrate filters. The filters were washed 10 times with $5 \%$ ice-cold TCA and counted by liquid scintillation counting. The incorporated ${ }^{3} \mathrm{H}$-thymidine was converted to cell production using a conversion factor of $1.1 \times 10^{18}$ cells $\mathrm{mol}^{-1}$ thymidine incorporated (Riemann et al. 1987). The incorporated ${ }^{3} \mathrm{H}$-leucine was converted to carbon according to Simon \& Azam (1989). Bacterial substrate consumption was estimated from the production rate assuming a growth yield of $40 \%$ (Bjørnsen \& Kuparinen 1991).

Nanoflagellates. The abundances of autotrophic and heterotrophic nanoflagellates were determined by epifluorescence microscopy on preparations stained with proflavine hemisulfate (Haas 1982). Samples were fixed by the addition of glutaraldehyde $(0.5 \%$ final concentration). After filtration, the filters were dried, mounted in paraffin oil and stored at $6^{\circ} \mathrm{C}$. Discrimination between autotrophic and heterotrophic flagellates was facilitated using green excitation to reveal pure chlorophyll autofluorescence. The diameters of 50 cells were measured on each preparation and cell volumes were calculated assuming spherical shape. Biovolume was converted to biomass using a conversion factor of $0.12 \mathrm{pg} \mathrm{C} \mu \mathrm{m}^{-3}$ (Fenchel 1982). The consumption and production of heterotrophic flagellates and microzooplankton were estimated assuming a clearance rate of $10^{5}$ body volumes $\mathrm{h}^{-1}$ (Fenchel 1986) and a growth yield of $40 \%$.

Ciliates and heterotrophic dinoflagellates. Samples for the determination of biomass were taken at 5 depths at all stations. The samples $(300 \mathrm{ml})$ were fixed in $1 \%$ Lugol's solution and counted after overnight settlement using a Leitz inverted microscope. Identification of ciliates to species or morphological types was based on Leegaard (1915), Kahl (1932) and Lynn et al. (1988). The dinoflagellates were identified according to Dodge (1985). The ratio between autotrophic and heterotrophic dinoflagellates was determined using epifluorescence as described for the nanoflagellates. Biovolumes were estimated from measurements of linear dimensions and assuming simple geometrical shapes. The biovolumes were converted to carbon using conversion factors of $0.071,0.11$ and 0.13 for ciliates (Fenchel \& Finlay 1983), 


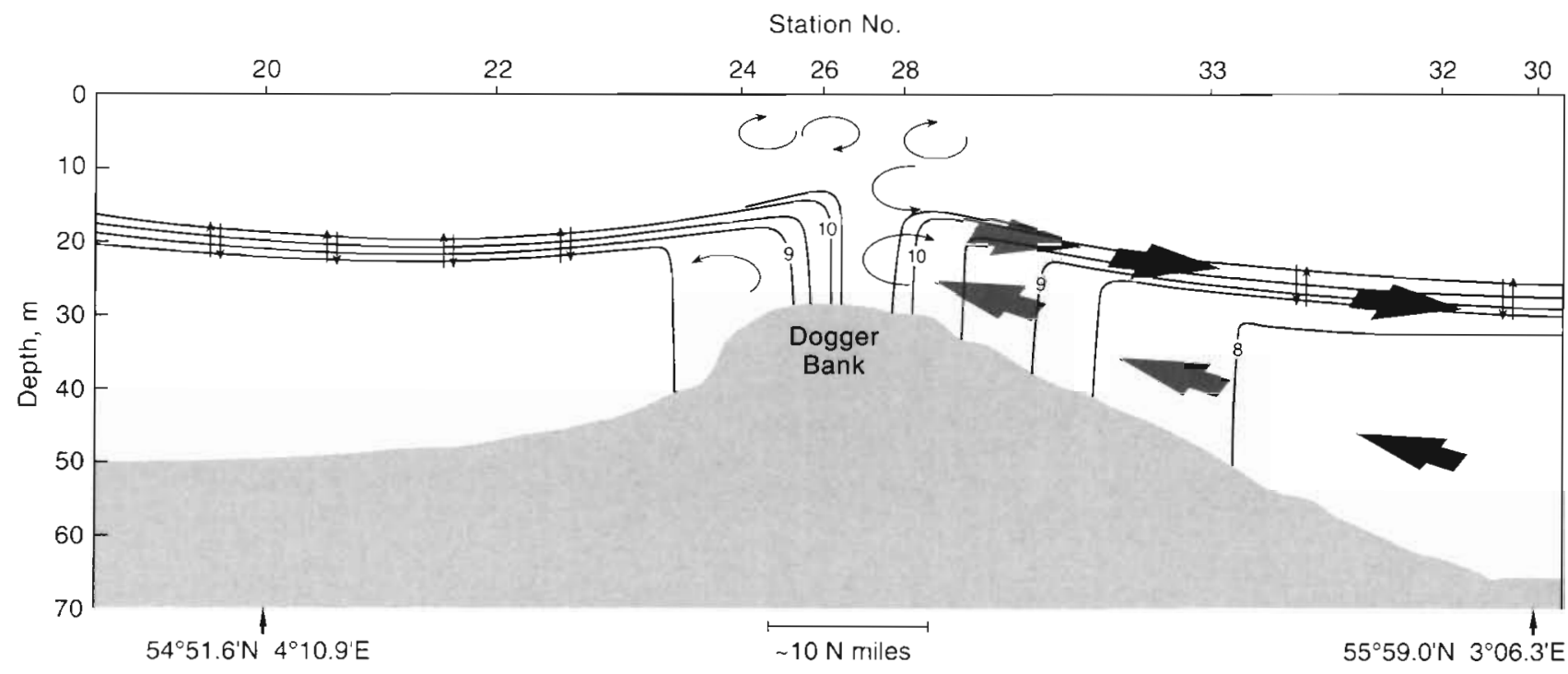

Fig. 2. Schematic presentation of the water column structure along Transect 1 (Stns 20 to 30, see Fig. 1). Isolines indicate temperature and arrows the prevailing currents and mixing processes. Modified from Bo Pedersen (1993)

athecate and thecate dinoflagellates (Edler 1979) respectively. The consumption and production of ciliates and heterotrophic dinoflagellates was estimated as for the heterotrophic flagellates.

Mesozooplankton. The vertical distribution of mesozooplankton was investigated using a submersible pump (3000 $\left.1 \mathrm{~min}^{-1}\right)$ raised through the water column at $10 \mathrm{~m} \mathrm{~min}^{-1}$. Sampling was carried out in 3 depth strata: below, within and above the pycnocline. The samples were successively filtered through 200, 100 and $30 \mu \mathrm{m}$ mesh nets and the retained fractions were fixed in buffered formalin ( $2 \%$ final concentration). Back in the laboratory, zooplankters in subsamples were counted and identified. In the case of copepods, at least 500 individuals were staged and sexed in each fraction. Abundance data for copepods were converted to biomass by means of length-weight regressions cited in Kiørboe \& Nielsen (1990).

Copepod egg production was determined according to Kiørboe et al. (1985). Adult females were sampled using a $200 \mu \mathrm{m}$ WP-2 net. Immediately after collection, fertilized females were added to $600 \mathrm{ml}$ bottles ( 1 to 5 females per bottle) containing $180 \mu \mathrm{m}$ prescreened surface water. The bottles ( 5 to 8 per species) were incubated in a thermostated room on a rotating wheel $(0.5 \mathrm{rpm})$ at in situ temperature $\left( \pm 2^{\circ} \mathrm{C}\right)$ for $24 \mathrm{~h}$. At the end of the experiment, the spawned eggs were counted. Production of the copepods was calculated from the specific egg production rates assuming equal specific egg production and juvenile growth rates (Berggreen et al. 1988). Ingestion was calculated from the production rate assuming a gross effiency of $33 \%$ (Peterson 1988).

\section{RESULTS}

During the study period, southeasterly winds dominated (5 to $10 \mathrm{~m} \mathrm{~s}^{-1}$ with peaks of up to 15 to $18 \mathrm{~m} \mathrm{~s}^{-1}$ ). A detailed description of the hydrographic conditions during this cruise appears elsewhere (Bo Pedersen 1993). However, a schematic diagram roughly depicting the prevailing currents and mixing processes (according to Bo Pedersen 1993) at and in the proximity of the Dogger Bank is shown in Fig. 2.

At the deep stratified stations north of the Dogger Bank, tidal activity results in turbulence restricted to the lower part of the bottom layer. At the shallow northern edge of the Bank, the tidal mixing results in a total vertical mixing of the bottom layer $(20$ to $45 \mathrm{~m}$ ). Along the northern slope, tidally mediated bottom turbulence results in a mixing of nutrient-rich cold bottom water $\left(7.4^{\circ} \mathrm{C}\right)$ with nutrient-depleted warm surface water $\left(11.5^{\circ} \mathrm{C}\right)$. This mixing creates water with a density between that of the surface and bottom waters which intrudes between these layers. This nutrientenriched intrusion layer is then dispersed over the region north of the Bank (Fig. 2).

\section{Hydrography and nutrient distribution}

Isopleths of temperature, sigma-t, fluorescence, nitrate and phosphate along Transects 1 and 2 are shown in Figs. $3 \& 4$. The water within the region investigated was almost vertically and horizontally isohaline. As a result, the sigma-t distribution is mainly controlled by the water temperature. Both north and 
Table 1. Maximum fluorescence and the ratio between the peak fluorescence and fluorescence in surface water $(2.5 \mathrm{~m})$ north, on and south of the Dogger Bank \pm SD

\begin{tabular}{|lccc|} 
& South & Bank & North \\
\hline $\begin{array}{l}\text { Number of stations } \\
\text { Maximum fluorescence }\end{array}$ & $5.8 \pm 2.3$ & $3.3 \pm 1.8$ & $6.9 \pm 3.3$ \\
$\begin{array}{l}\text { (arbitrary units) } \\
\mathrm{Fl} \text { max } / \mathrm{Fl}\end{array}$ sm & $12.6 \pm 1.7$ & $2.8 \pm 1.7$ & $10.9 \pm 5.6$ \\
\hline
\end{tabular}

south of the Dogger Bank, the water column was thermally stratified, with a temperature decrease from $11^{\circ} \mathrm{C}$ in the surface to about $7^{\circ} \mathrm{C}$ in the bottom water. The stratification was stronger south of the Bank. At the Bank (Stns 24 to 28), the water column was almost vertically mixed.

The nutrient concentrations were low south of Stn 28 and in the surface water of the northern stations $\left(\mathrm{NO}_{3}{ }^{-}\right.$ below detection level and $\mathrm{PO}_{4}{ }^{3-}<0.3 \mu \mathrm{M}$ ). Higher values were measured in the bottom water north of the Bank with average concentrations of about 4 and $0.5 \mu \mathrm{M}$ for nitrate and phosphate, respectively (Figs. $3 d$, e \& 4 d, e).

\section{Phytoplankton biomass, production and composition}

The distribution pattern of the fluorescence roughly followed the thermal stratification. The fluorescence in the surface water was generally low and evenly distributed along the 2 transects. The highest fluorescence values in the immediate region of the Dogger Bank were recorded in the bottom water associated with the fronts at the edges of the Bank. In addition, high values were recorded in the bottom water south of the Bank. The fluorescence peaked in a subsurface layer near the pycnocline at the deeper stations north of the Bank with values corresponding to $4.1 \mu \mathrm{g} \mathrm{chl} \mathrm{a}$ $1^{-1}$ (Fig. 3c \& 4c).

Fluorescence data sampled in this study (from 51 hydrographical and biological stations) are presented in Table 1. In general, the subsurface fluorescence peak was narrowest in the region north of the Bank, where the highest values were measured within or just below the pycnocline associated with the nutricline. At the shallow mixed Bank stations, fluorescence was relatively low throughout the water column. In addition, although there was slightly more fluorescence deeper in the water column over the Bank than at the surface,

Fig. 3. Vertical distributions of (a) temperature, (b) sigma-t, (c) fluorescence, (d) nitrate and (e) phosphate along Transect 1. Dots indicate sampling depths
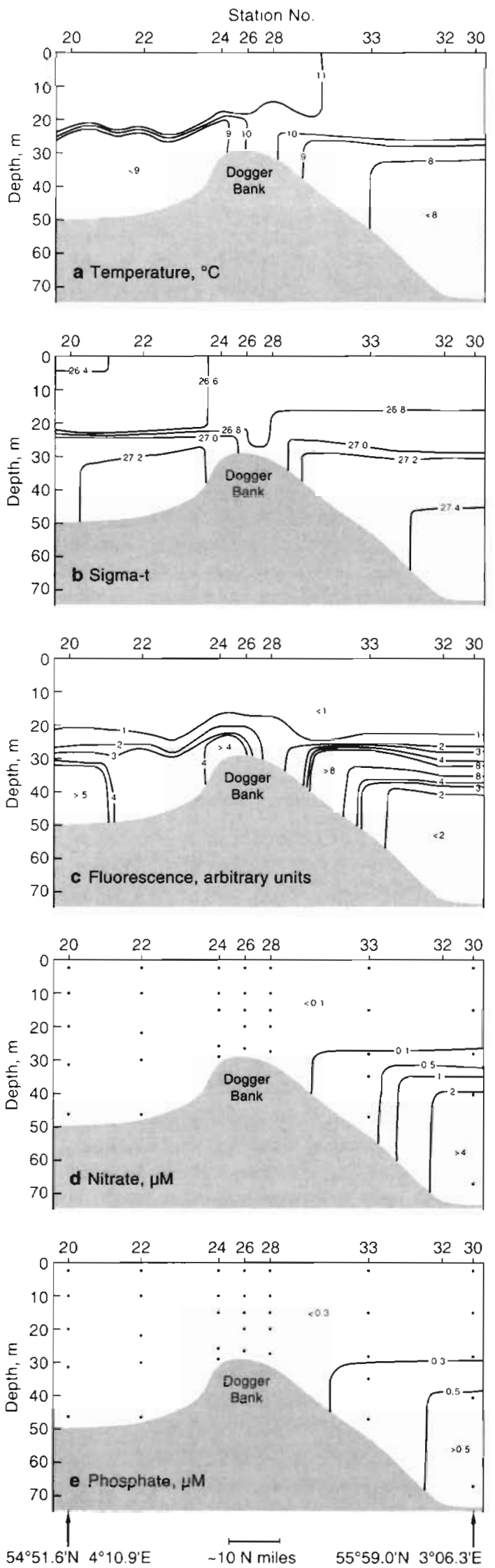

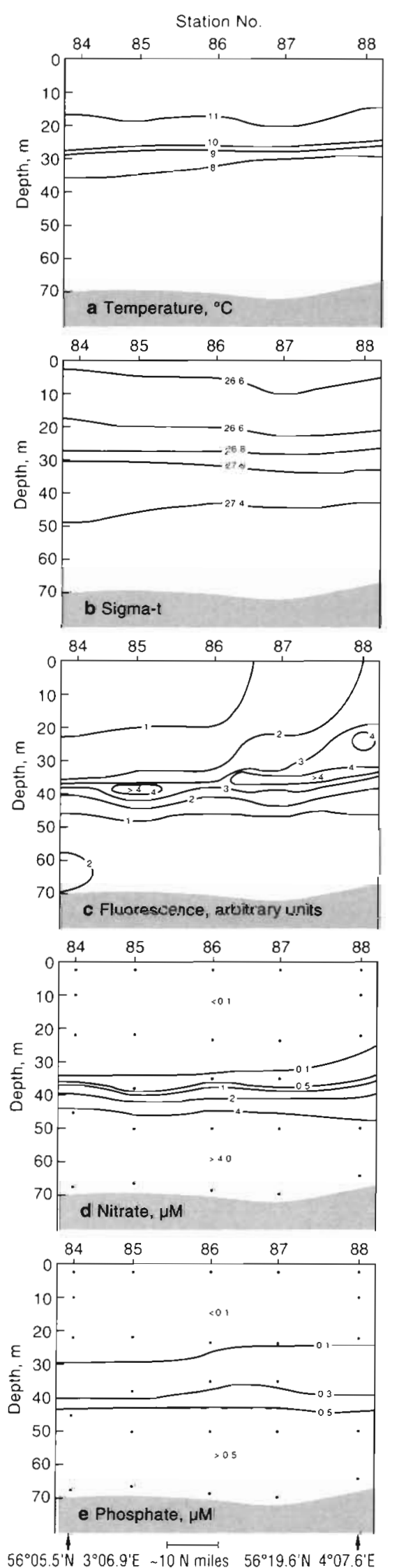

the differences in fluorescence throughout the water column were much smaller here than in the other regions examined. South of the Bank, the highest values of fluorescence were recorded in the bottom water below the pycnocline.

Total water column primary production ranged from approximately 200 to over $700 \mathrm{mg} \mathrm{C} \mathrm{m}^{-2} \mathrm{~d}^{-1}$, with the greatest values being recorded on Transect 2 (Stn 88) and the lowest at the Dogger Bank stations along Transect 1 . The distribution of primary production throughout the water column along the transects followed the same general pattern as the distribution of phytoplankton biomass (Fig. 5a). High production (>10 $\mu \mathrm{g} \mathrm{C} \mathrm{l}^{-1}$ $\mathrm{d}^{-1}$ ) was associated with the bottom fronts at the northern and southern edges of the Bank. High production was measured throughout the water column at $\operatorname{Stn} 28$ associated with the mixing of nutrient-rich bottom and surface water.

Although biomass distributions indicated the presence of a subsurface phytoplankton peak along Transect 2 , the primary production associated with this peak was not as great as that along Transect 1 (Figs. 4c $\& 6$ a). On Transect 2 , the primary production peaked in

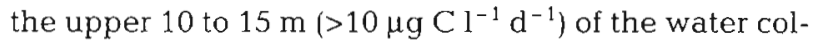
umn at Stns $84 \& 85$, while the highest production (>15 $\mu \mathrm{g} \mathrm{Cl}^{-1} \mathrm{~d}^{-1}$ ) was measured within the subsurface peak on the westernmost stations along this transect (Fig. 6b).

The size-fractionated chl a and primary production showed that the major part of the biomass and production could be attributed to the $<11 \mu \mathrm{m}$ phytoplankton fraction (Fig. 7). The observed patterns in the size-fractionated chl $a$ and primary production were supported by the microscopic analysis of the plankton which revealed that the plankton flora was dominated by a mixture of $<10 \mu \mathrm{m}$ flagellates. The numerically dominant groups/species were: chrysophyceae [Apendinella spinefera $(10 \mu \mathrm{m})$, Emiliana huxleyi ( 3 to $5 \mu \mathrm{m})$, Pseudopedinella elastica, $P$. pyriformis (5 to $7.5 \mu \mathrm{m})$ ], Cryptophyceae [Plagioselmis prolonga, Teleaulax acuta $(3$ to $10 \mu \mathrm{m})]$, Dinophyceae [Heterocapsa minima (6 to $10 \mu \mathrm{m}$ ) and Prorocentrum balticum (5 to $7 \mu \mathrm{m}$ )] and Prymnesiophyceae [Chrysochromulina spp. (5 to $10 \mu \mathrm{m})$, Imantonia rotundata (2 to $3 \mu \mathrm{m}$ ) and Phaeocystis pouchetti $(5 \mu \mathrm{m})$ ]. Few diatoms [Chaetoceros sp. (5 to $10 \mu \mathrm{m})$, Nitzschia sp. and Thalassiosira sp.] were identified.

The vertical distribution of the obligate autotrophic ciliate Mesodinium rubrum along the 2 transects paralleled the distribution of the fluorescence. Low abun-

Fig. 4. Vertical distributions of (a) temperature, (b) sigma-t, (c) fluorescence, (d) nitrate and (e) phosphate along Transect 2 . Dots indicate sampling depths 
dance of this organism was observed above the pycno-

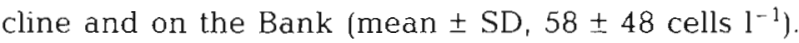
High abundances were observed in the bottom waters at Stns 20 and 22 and in association with the intrusion layer north of the Bank (mean \pm SD, $420 \pm 147$ and

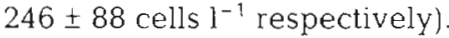

\section{Bacterial biomass and production}

There were no significant differences in bacterial cell size between depths or stations. The average cell size was $0.081 \pm 0.0033 \mu \mathrm{m}^{3}(\mathrm{n}=1200)$. The biomass south of the Bank was $<5 \mu \mathrm{g} \mathrm{C} \mathrm{l^{-1 }}$ (corresponding to

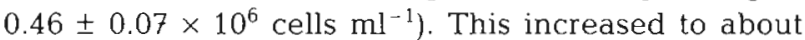
$20 \mu \mathrm{g} \mathrm{C} \mathrm{l}^{-1}$ (corresponding to $2.08 \pm 0.64 \times 10^{6}$ cells $\mathrm{ml}^{-1}$ ) on the Bank and within and below the pycnocline at Stn 33 (Fig. 5c). Along Transect 2, the bacterial biomass peaked in the subsurface phytoplankton peak with a biomass of about $20 \mu \mathrm{g} \mathrm{C}^{-1}$ (corresponding to $1.6 \pm 0.37 \times 10^{6}$ cells $\mathrm{ml}^{-1}$ ) (Fig. $6 \mathrm{c}$ ).

The distribution of bacterial production (as determined by both methods) roughly mirrored the trends in the distribution of the phytoplankton biomass and production. Generally, there was good correlation between the 2 methods used to estimate bacterial production. A linear regression analysis showed a significant correlation $\left(\mathrm{r}^{2}=0.57, \mathrm{n}=79, \mathrm{p}<0.001\right)$ between thymidine and leucine incorporation. South of the Bank, the production was $<2 \mu \mathrm{g} \mathrm{C} \mathrm{l}^{-1} \mathrm{~d}^{-1}$ with the exception of $\operatorname{Stn} 20$ where the production in the bottom water increased to $>3 \mu \mathrm{gCl}^{-1} \mathrm{~d}^{-1}$ associated with the high chl a values. On the Bank and within the subsurface phytoplankton peak north of the Bank, the bacterial production increased to $>3 \mu \mathrm{g} \mathrm{Cl}^{-1} \mathrm{~d}^{-1}$. The highest production was measured in the bottom water at Stns $24 \& 26$ (>6 $\mu \mathrm{g} \mathrm{C}^{-1} \mathrm{~d}^{-1}$ ) (Figs. 5d, e \& 6d, e).

\section{Nanoflagellates}

The abundance of heterotrophic and autotrophic nanoflagellates varied considerably in the area investigated $\left(0.5\right.$ to $8.0 \times 10^{3} \mathrm{ml}^{-1}$ and 0.5 to $25 \times 10^{3} \mathrm{ml}^{-1}$, respectively). Mean cell volumes of the heterotrophic and autotrophic nanoflagellates were 54 and $84 \mu^{3}$, respectively. The biomass of heterotrophic nanoflagel-

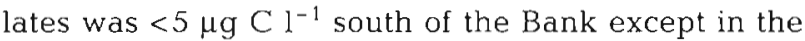
bottom waters of Stns $20 \& 22$. Higher biomasses

Fig. 5. Vertical distributions of (a) chlorophyll $a$, (b) primary production, (c) bacterial biomass, and bacterial production measured as incorporation of (d) thymidine and (e) leucine along Transect 1. Dots indicate sampling depths
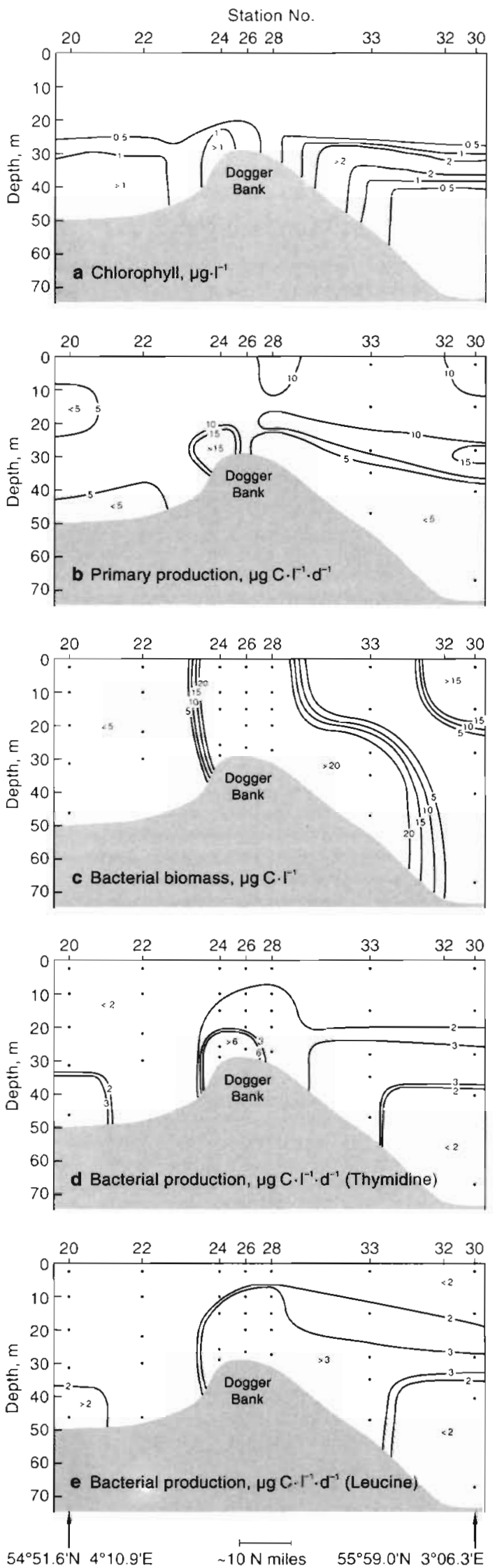

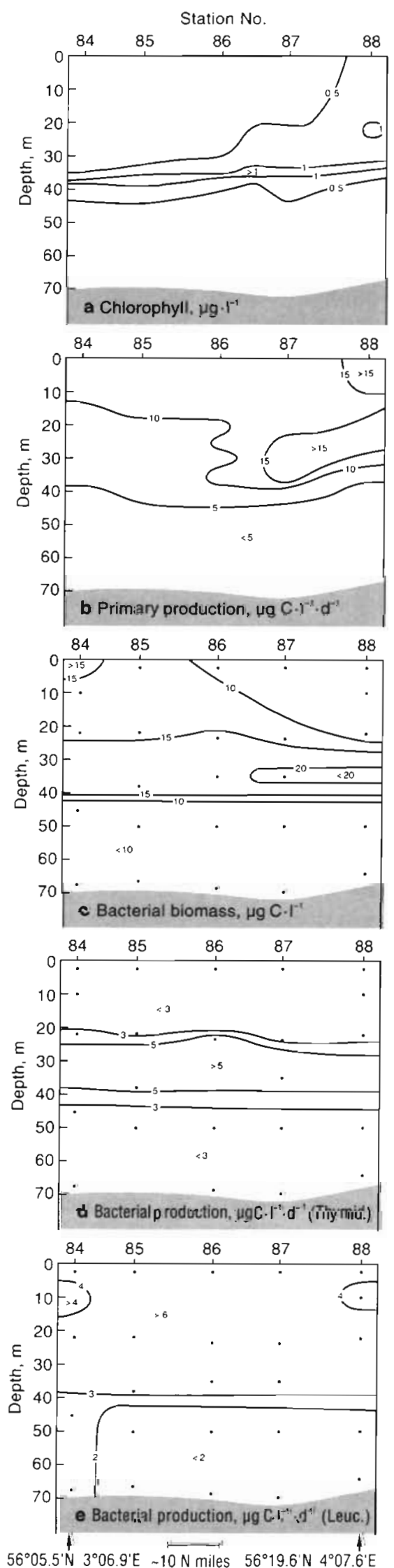

( $>20 \mu \mathrm{g} \mathrm{Cl}^{-1}$ ) were found north of the Bank associated with the pycnocline (Figs. 8 b \& 9b). The distribution pattern of the autotrophic flagellates resembled that of the fluorescence. Low biomasses were recorded south of the Bank; higher biomasses were recorded north of the Bank associated with the subsurface phytoplankton peak (Figs. 8a \& 9a).

\section{Heterotrophic dinoflagellates and ciliates}

Small Gymnodinium spp. ( 7 to $10 \mu \mathrm{m}$ ) dominated the heterotrophic dinoflagellate biomass. Larger less abundant species such as $G$. dominans, G. glaucum and $G$. spirale were also identified in most samples. In the bottom samples, few thecate dinoflagellates were observed. Of those observed, Protoperidinium bipes was most abundant. The abundance of heterotrophic dinoflagellates ranged from 0.4 to $27 \times 10^{3}$ cells $l^{-1}$. The vertical distribution of the heterotrophic dinoflagellates paralleled the fluorescence distribution, with the highest biomasses being recorded in the bottom water south of the Bank, in the frontal zones on the edges of the Bank and within the subsurface plankton peak north of the Bank (Figs. 8c \& 9c).

Ciliates constituted the major part of the microzooplankton on all sampling occasions. A total of 20 species or morphotypes were identified. Abundances ranged from $0.5 \times 10^{3}$ to $5.8 \times 10^{3}$ cells $1^{-1}$. Naked oligotrichs dominated (Lohmaniella oviformis, L. spiralis, Laboea coronata, Strombidium ovale, S. emergens and Tontonia spp.). Tintinnids (dominated by Stenosomella sp. and Tintinnopsis sp.) comprised 0 to $25 \%$ (mean \pm SD, $2.3 \pm$ $4.8 \%$ ) of the biomass north of Stn 26 . However, a greater contribution by tintinnids was found south of $\operatorname{Stn} 26$ (0 to $62 \%$ ) (mean $\pm 1 \mathrm{SD}, 18.4 \pm 18.8 \%$ ).

The vertical distribution of the ciliate biomass is shown in Figs. 8d \& 9d. High biomasses (>10 $\mu \mathrm{g} \mathrm{Cl}^{-1}$ ) were measured on the Bank and in association with the subsurface plankton peak north of the Bank. South of the Bank, in the bottom and surface waters of the deeper northern stations, the biomass was considerably lower ( 1 to $5 \mu \mathrm{g} \mathrm{Cl}^{-1}$ ).

\section{Mesozooplankton}

Copepods dominated the mesozooplankton and a total of 11 species or genera were identified in the sam-

Fig. 6. Vertical distribution of (a) chlorophyll $a_{\text {, }}$ (b) primary production, (c) bacterial biomass, and bacterial production measured as incorporation of (d) thymidine and (e) leucine along Transect 2 . Dots indicate sampling depths 

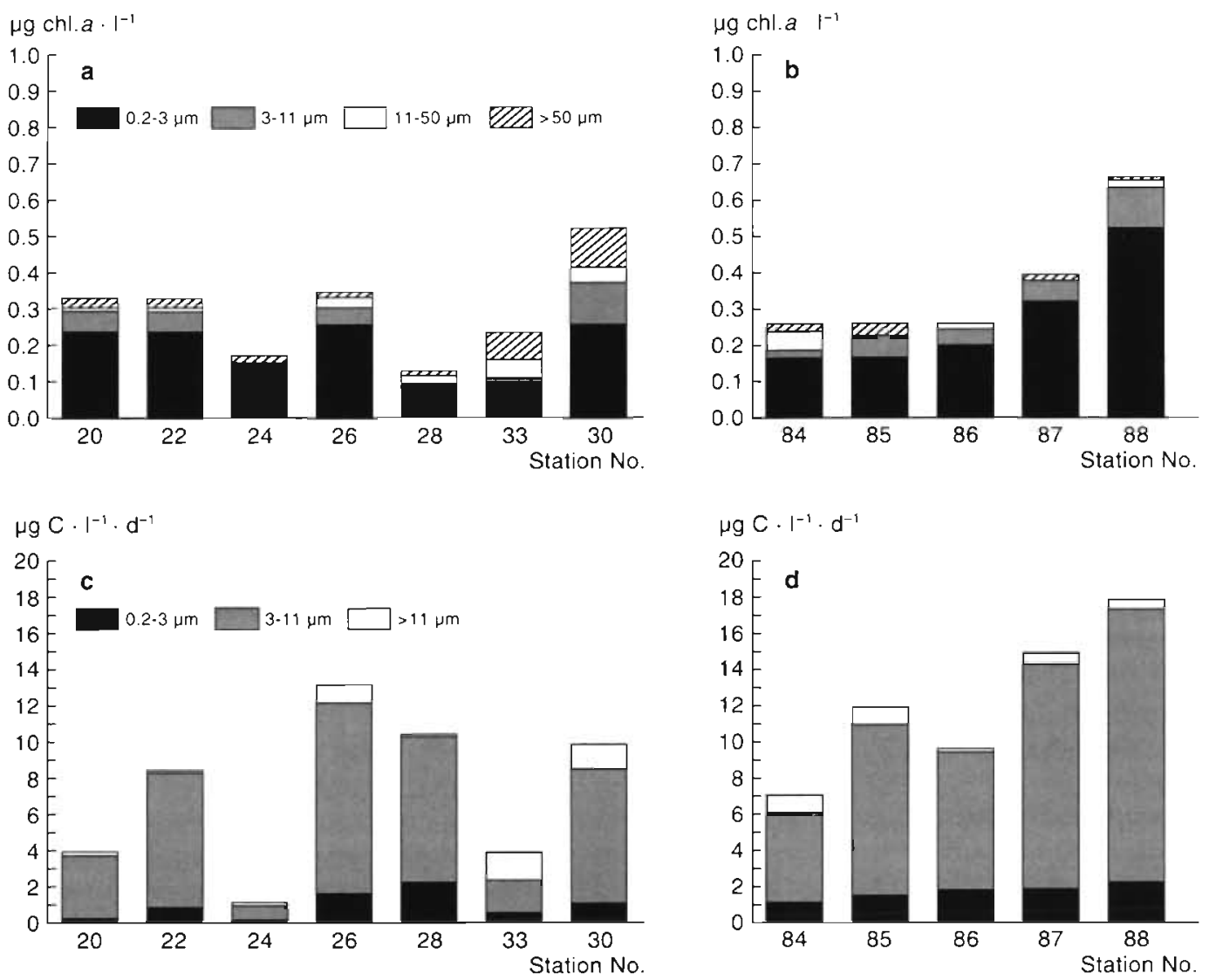

Fig. 7. Fractionated chlorophyll $a$ and primary production at $2.5 \mathrm{~m}$ along Transects $1(\mathrm{a}, \mathrm{c}$ ) and 2 (b, d)

ples. Of these, Oithona spp. dominated the copepod community on and north of the Bank with a contribution to the biomass of 67 to $69 \%$ (mean $\pm \mathrm{SD}, 66 \pm 1 \%$ ) and 30 to $54 \%$ (mean $\pm \mathrm{SD}, 39 \pm 9 \%$ ), respectively. South of the Bank, Temora longicornis (52\%) and Pseudocalanus sp. (43\%) dominated at Stns $20 \& 22$, respectively. At the stations located south of and on the Dogger Bank (Stns 20 to 28), Calanus sp. constituted 2 to $21 \%$ (mean $\pm \mathrm{SD}, 8 \pm 8 \%$ ) of the copepod biomass. North of the Bank (Stns $30 \& 33$ and Transect 2), Calanus sp. comprised 24 to $41 \%$ (mean $\pm \mathrm{SD}, 28 \pm 9 \%$ ) of the copepod biomass. Along Transect 1 (Fig. 8e), the copepod biomass peaked in association with the pycnocline, except in the bottom water at Stns $26 \& 28$ where the highest biomasses were measured just above the bottom, associated with the mixing of the nutrient-rich bottom water. On Transect 2, no consistent relationship with depth or time of the day was apparent (Fig. 9e).

The egg production rates of the copepods are shown in Table 2. Egg production was generally higher at the stations north of the Bank. The trend in the egg production measurements was supported by the abundance of copepod nauplii (Fig. 10a, b). High abun- dances and biomasses were recorded along the transect north of the Bank compared with the values found on and in proximity of the Bank.

The non-copepod zooplankters were dominated by lamellibranch veliger larvae and the planktonic gastropod Limacina spp. Along Transect 1, high abundances of lamellibranch veliger larvae were found associated with the frontal area on the northern and southern edges of the Bank. In general, the abundance of non-copepod zooplankters was higher along Transect 2 , here dominated by the planktonic gastropods (Fig. 10c, d).

\section{DISCUSSION}

\section{Subsurface phytoplankton peaks}

The traditional description of the seasonal distribution of plankton activity in the North Sea applies only to the surface water (e.g. Cushing 1973). In this and other studies, the presence of a subsurface peak of phytoplankton in and around the pycnocline in the stratified waters around the Dogger Bank has been 

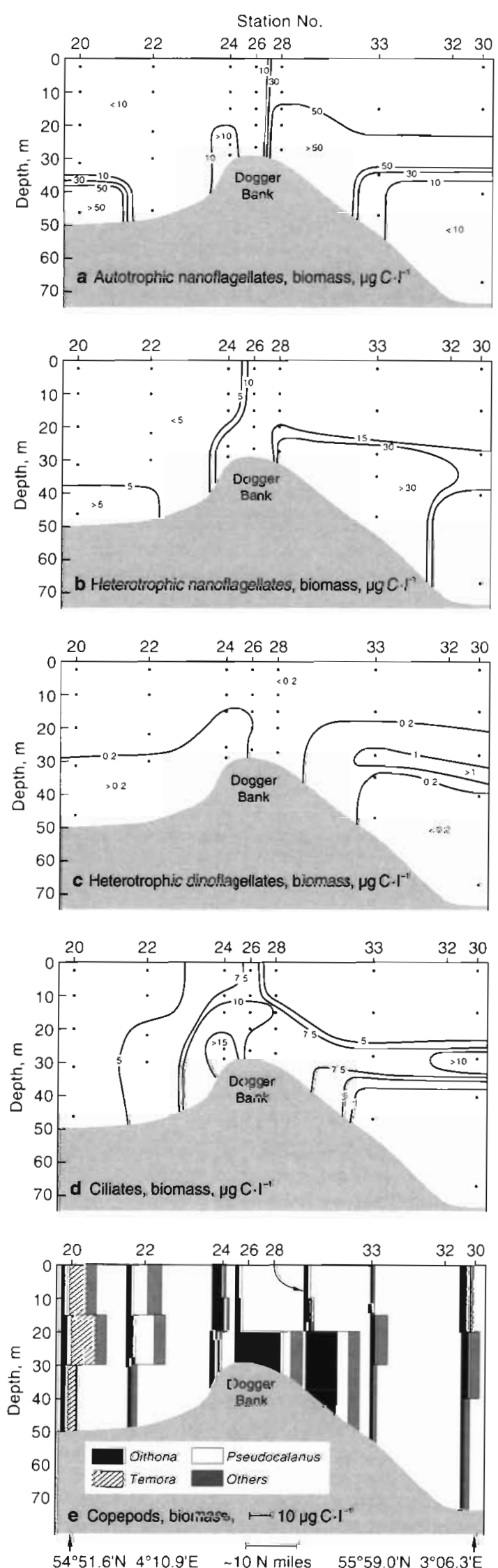

identified (e.g. Riegman et al. 1990). The geographic and temporal boundaries and the impact on the distribution and production of the zooplankton of these subsurface phytoplankton peaks are, as yet, not well described. Thus, it is not possible to quantify the importance of these subsurface phytoplankton populations to the total production of the North Sea.

However, the presence of active subsurface phytoplankton populations and their potentially significant contribution to the total production have recently been realised for a number of seas bordering the North Sea. The presence of an active subsurface phytoplankton layer has been demonstrated by Richardson (1985), Kiørboe et al. (1990) and Bjørnsen et al. (1993) in the Skaggerak and by Nielsen et al. (1990) and Kaas et al. (1991) in the Kattegat.

In a study of the seasonal distribution and production of phytoplankton in the southern Kattegat, Richardson \& Christoffersen (1991) documented the quantitative importance of subsurface blooms over an annual cycle. In that study, it was estimated that subsurface phytoplankton populations accounted for approximately $30 \%$ of the annual primary production compared with a contribution of approximately $19 \%$ from the spring bloom.

At all the CTD stations investigated during this study, fluorescence maxima at depths greater than $15 \mathrm{~m}$ were observed (Table 1). At many stations, this maximum was recorded at depths of between 30 and $40 \mathrm{~m}$. Light penetration to $30 \mathrm{~m}$ was 1.5 to $5.0 \%$ of surface values and primary production determinations made on samples taken from these depths show that these subsurface peaks were comprised of actively photosynthesizing phytoplankton. Primary production estimates for the entire water column suggest that photosynthesis in subsurface peaks could account for up to $70 \%$ of total water column production at this time.

\section{Size distribution of the phytoplankton and structure of the food web}

Most investigations of North Sea plankton dynamics focus on the link between the phytoplankton and the larger copepods. During this study, small phytoplankton $(<11 \mu \mathrm{m})$ dominated the phytoplankton biomass. Microscopic examination showed that 5 to $7 \mu \mathrm{m}$ autotrophic flagellate species dominated the phytoplankton. Particles of this size approach the lower limit of the

Fig. 8. Vertical biomass distributions of (a) autotrophic nanoflagellates, (b) heterotrophic nanoflagellates, (c) heterotrophic dinoflagellates, (d) ciliates and (e) copepod biomass along Transect 1. Dots indicate sampling depths 
food size spectra for adult copepods (Berggreen et al. 1988) and are thus grazed with low effiency. On average, the $<11 \mu \mathrm{m}$ phytoplankton fraction contributed 82 $\pm 12 \%$ and $85 \pm 14 \%$ of the total phytoplankton biomass and production, respectively (Fig. 11).

Small cell size may be a competitive advantage in a nutrient-depleted and stratified environment compared to larger cell sizes (Fenchel 1988, Kiørboe 1993). In this study, the ratio between the large and the small phytoplankton fraction was highest over the Dogger Bank and at the northern edge of the Bank where new nutrients are introduced at the pycnocline (Table 3). North of the Dogger Bank (towards the central North Sea), a succession towards a community production based on regenerated nutrients would be predicted as the nutrients in the intrusion layer become depleted. The decreasing ratio of fluorescence between large and small phytoplankton fractions with increasing distance from the northern edge of the Dogger Bank (Table 3) is consistent with the predicted shift from new to a greater proportion of regenerated production (Dugdale \& Goering 1967). It should be noted that grazing pressure by copepods on phytoplankton (expressed as a percentage of phytoplankton production ingested by copepods) was approximately equal at the northern edge of the Bank and on Transect 2 . Therefore, grazing pressure alone cannot explain the changes seen in the relative ratios of large to small cells in these 2 regions.

A similar trend in the distribution of small and large phytoplankton cells was observed by Kiørboe et al. (1990) along a transect through the Skagerrak. At the well-mixed coastal stations, where nutrients were plentiful, large diatoms dominated, while the phytoplankton at the stratified stations of the central Skagerrak was dominated by small flagellates.

\section{Carbon budgets}

We have established budgets for the flow of carbon between phytoplankton, bacteria, heterotrophic flagellates, micro-zooplankton and copepods for the investigated regions. On the basis of the bathymetric and hydrographic characteristics and nutrient distribution of the region we have chosen to illustrate the carbon flow model for 4 different regions within the study area: (A) the region south of the Bank, characterized by strong stratification and no measurable nutrients in

Fig. 9. Vertical biomass distributions of (a) autotrophic nanoflagellates, (b) heterotrophic nanoflagellates, (c) heterotrophic dinoflagellates, (d) ciliates and (e) copepods along Transect 2, Dots indicate sampling depths
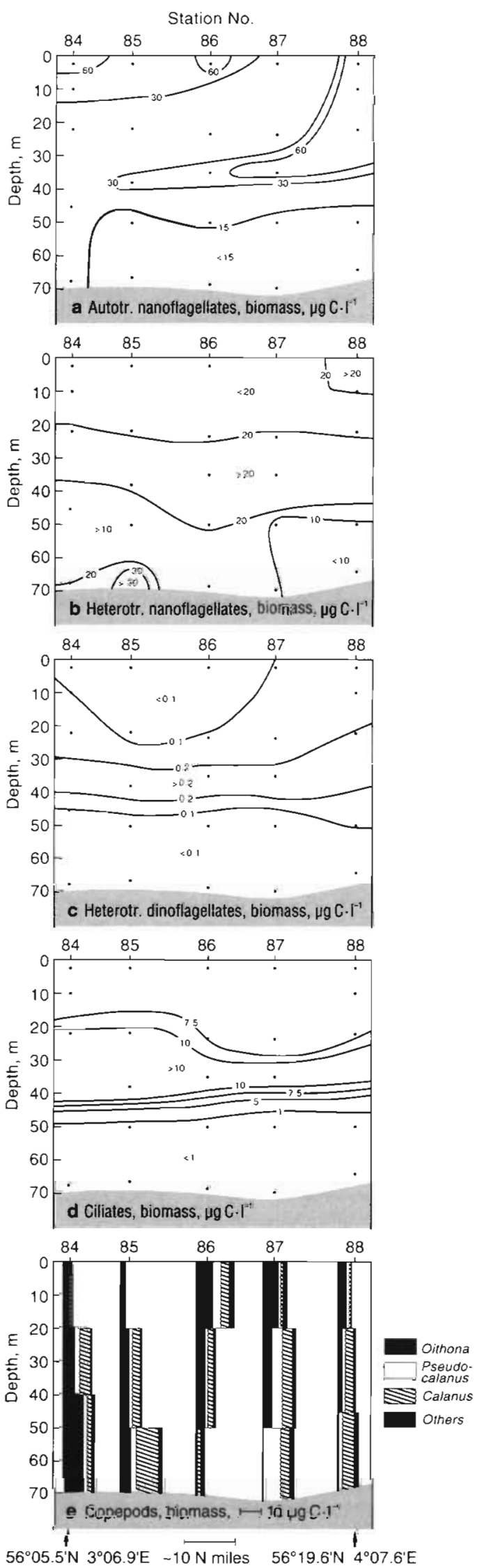
Table 2. Egg production (egg female ${ }^{-1} \mathrm{~d}^{-1}$, mean $\pm \mathrm{SD}$ ) of the dominating copepods along the 2 transects. No. of experiments in parenthesis; "no measurements

\begin{tabular}{|c|c|c|c|c|c|c|c|}
\hline \multirow{2}{*}{$\begin{array}{l}\text { Transect } 1 \\
\text { Species }\end{array}$} & \multicolumn{7}{|c|}{ Station } \\
\hline & 20 & 22 & 24 & 26 & 28 & 33 & 30 \\
\hline Calanus finmarchicus & $\begin{array}{c}8.6 \pm 9.5 \\
(4)\end{array}$ & $\begin{array}{c}8.9 \pm 1.7 \\
(4)\end{array}$ & $\cdot$ & $\begin{array}{l}9.8 \\
(1)\end{array}$ & $\begin{array}{c}9.4 \pm 2.0 \\
(6)\end{array}$ & $\begin{array}{c}18 \pm 4.2 \\
(4)\end{array}$ & $\begin{array}{c}20.8 \pm 10.2 \\
(5)\end{array}$ \\
\hline Centropages hamatus & $\cdot$ & $\cdot$ & $\cdot$ & $\cdot$ & $\begin{array}{c}13.8 \pm 0 \\
(2)\end{array}$ & $\cdot$ & $\begin{array}{c}25.0 \pm 7.1 \\
(2)\end{array}$ \\
\hline Centropages typicus & $\begin{array}{c}18.8 \pm 7.8 \\
(5)\end{array}$ & • & $\cdot$ & $\begin{array}{c}19.6 \pm 1.4 \\
(2)\end{array}$ & • & $\cdot$ & $\cdot$ \\
\hline Paracalanus parvus & $\begin{array}{c}3.2 \pm 0.8 \\
(5)\end{array}$ & $\begin{array}{c}1.2 \pm 0 \\
(2)\end{array}$ & $\begin{array}{c}2.7 \pm 0 \\
(2)\end{array}$ & $\begin{array}{l}2.8 \pm 1.2 \\
(4)\end{array}$ & $\begin{array}{c}4.0 \pm 1.9 \\
(4)\end{array}$ & $\begin{array}{c}7.9 \pm 2.1 \\
(4)\end{array}$ & $\begin{array}{c}5.0 \pm 1.1 \\
(4)\end{array}$ \\
\hline Temora Iongicornis & $\begin{array}{c}0.3 \pm 0.1 \\
\text { (4) }\end{array}$ & $\begin{array}{c}0.2 \pm 0 \\
(2)\end{array}$ & $\begin{array}{c}2.8 \pm 1.3 \\
(3)\end{array}$ & $\begin{array}{l}1.0 \\
(1)\end{array}$ & $\cdot$ & $\begin{array}{c}6.0 \pm 2.1 \\
\text { (3) }\end{array}$ & $\begin{array}{c}7.3 \pm 2.6 \\
(4)\end{array}$ \\
\hline \multicolumn{8}{|l|}{ Transect 2} \\
\hline Species & 84 & \multicolumn{2}{|c|}{85} & 86 & \multicolumn{2}{|c|}{87} & 88 \\
\hline Calanus finmarchicus & $\begin{array}{c}24.1 \pm 9.8 \\
\text { (5) }\end{array}$ & & 0.6 & $\begin{array}{c}10.6 \pm 12.3 \\
(6)\end{array}$ & \multicolumn{2}{|c|}{$\begin{array}{c}9.1 \pm 3.6 \\
(7)\end{array}$} & $\begin{array}{c}23.3 \pm 13 \\
(6)\end{array}$ \\
\hline Paracalanus parvus & $\begin{array}{c}2.4 \pm 1.7 \\
(5)\end{array}$ & & 0.5 & $\begin{array}{c}2.6 \pm 1.3 \\
(5)\end{array}$ & \multicolumn{2}{|c|}{$\begin{array}{c}0.6 \pm 0.3 \\
(5)\end{array}$} & $\begin{array}{c}2.4 \pm 1.7 \\
(5)\end{array}$ \\
\hline Temora longicornis & $\begin{array}{c}4.6 \pm 1.6 \\
(2)\end{array}$ & & 9.4 & • & \multicolumn{2}{|c|}{$\begin{array}{c}4 \pm 2 \\
(2)\end{array}$} & $\begin{array}{c}3.9 \pm 1.5 \\
(2)\end{array}$ \\
\hline Acartia sp. & $\cdot$ & & & $\begin{array}{c}2.0 \pm 0 \\
(2)\end{array}$ & \multicolumn{2}{|c|}{ • } & $\cdot$ \\
\hline
\end{tabular}

the bottom water (Stns 20 \& 22); (B) the Dogger Bank, characterized by a shallow and mixed water column (Stns 24 to 28); (C) the northern edge of the Bank characterized by the upwelling of nutrient rich bottom water (Stns 30 \& 33); and (D) the deep stratified stations some distance from the Bank, i.e. Transect 2 (Stns 84 to 88 ) (Fig. 11).

We recognize that the established carbon budgets represent 'snapshots' of highly dynamic plankton communities which are composed of rapidly fluctuating populations of microorganisms and more stable populations of mesozooplankton, and that the few data in each region are insufficient to test the significance of the differences observed between regions. However,

Table 3. Fraction of phytoplankton biomass and production due to cells $>11 \mu \mathrm{m}$ expressed as a percentage of the total phytoplankton biomass and production

\begin{tabular}{|lccccc|}
\hline & & \multicolumn{3}{c}{ Region } & \\
& 1 & 2 & 3 & 4 \\
& $($ Stns 20, 22) & (Stns 24-28) & (Stns 30, 33) & (Stns 84-88) \\
\hline Biomass & 11 & 16 & 38 & 11 \\
$\begin{array}{l}\text { Primary } \\
\text { production }\end{array}$ & 6 & 5 & 20 & 6 \\
\hline
\end{tabular}

we belive that the exercise is useful as a starting-point in an examination of the potential for heterogeneity in patterns of carbon flow in the North Sea.

The carbon budget seems to balance well between bacterioplankton and heterotrophic nanoflagellates in all areas, except on the northern edge of the Bank (Fig. 11c), where bacterial production alone appears to be insufficient to satisfy the calculated carbon demand of the nanoflagellates. Bacterio- and picoplankton production together would, however, be able to provide the major part of the heterotrophic nanoflagellate carbon demand. Heterotrophic nanoflagellate production alone could supply only 12 to $43 \%$ of the carbon demand of the microzooplankton in the study area. However, if the phytoplankton of $<11 \mu \mathrm{m}$ is considered together with the heterotrophic nanoflagellate production, the carbon budget seems to balance.

The bacterial abundances and production found during this investigation are slightly higher than the ranges measured by Van Duyl et al. (1990) in the Dogger Bank area. However, the bacterial abundances found during our investigation fall within the range for the North Sea presented in a review by Billen et al. (1990). 

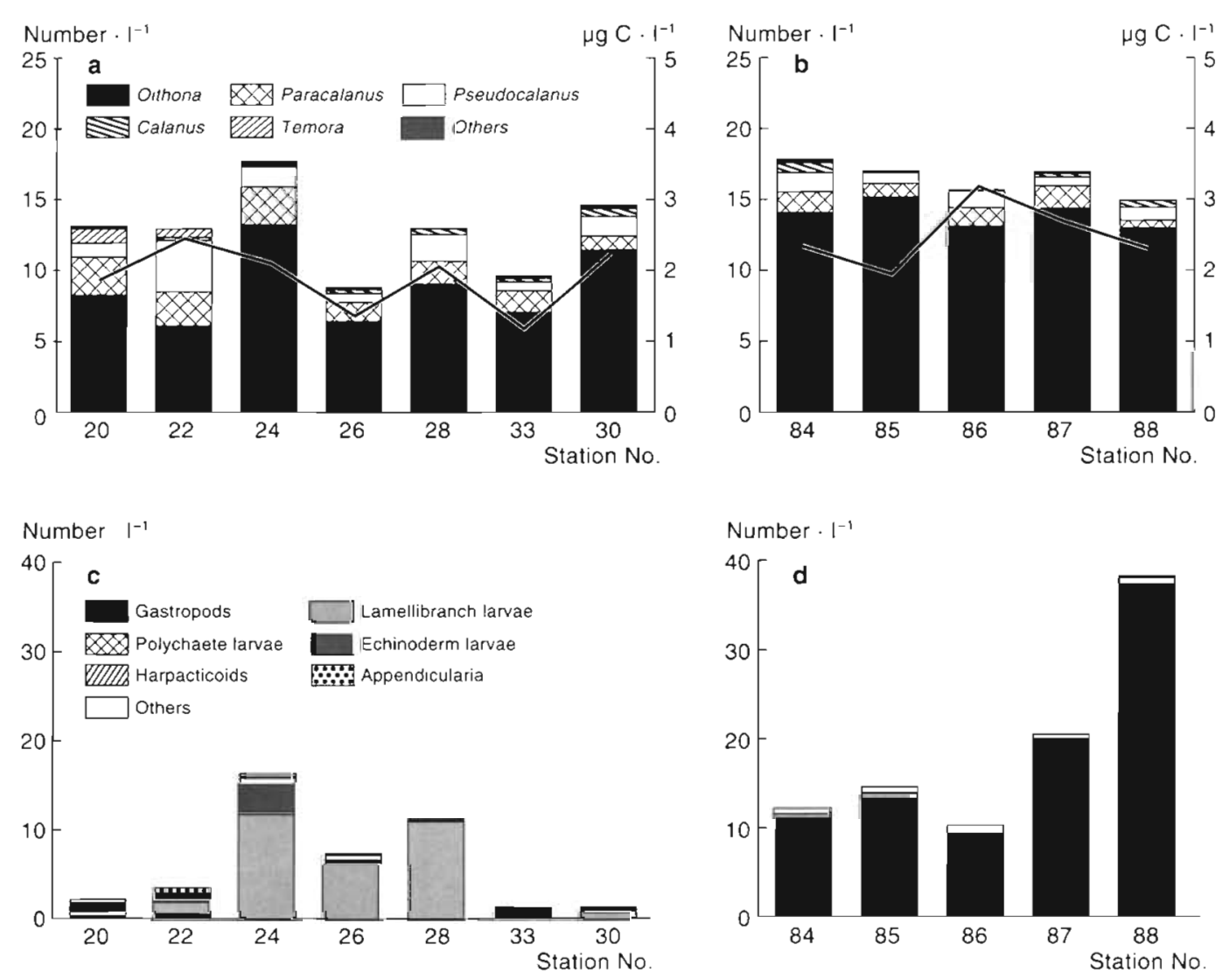

Fig. 10. Average abundances (bars indicating number $\mathrm{l}^{-1}$ ) and biomasses (solid line showing $\mu \mathrm{g} \mathrm{C} \mathrm{l}^{-1)}$ of $(\mathrm{a}, \mathrm{b}) \mathrm{copepod}$ nauplii and $(c, d)$ other zooplankters through the water column along the 2 transects

Our measurements of the abundance of auto- and heterotrophic nanoflagellates are also higher than the measurements and values cited in Van Duyl et al. (1990). However comparable heterotrophic flagellate abundances have been found in the central North Sea in May-June (Nielsen \& Richardson 1989).

To our knowledge, no other data on the abundance of ciliates and heterotrophic dinoflagellates are available for the North Sea. The abundance of ciliates is within the range reported from other marine areas (Pierce \& Turner 1992). The abundance of heterotrophic dinoflagellates is comparable to the range given by Lessard (1991) from the North Atlantic.

The high biomasses of bacteria and protozooplankton observed suggest a potential importance of the microbial loop in the carbon dynamics in the North Sea during this investigation (Fig. 11). The ratios between bacterial biomass and production and phytoplankton biomass and production are shown in Table 4 . The lowest ratios were found north and south of the Dogger Bank while the ratios increased and peaked on the Bank where the bacterial biomass was higher than the phytoplankton biomass and the bacterial production comprised 55 to $78 \%$ of the primary production. During their Febuary-March cruise in 1988, Nielsen \& Richardson (1989) observed the opposite trend. North and east of the Dogger Bank (i.e. in pre-spring bloom and post-bloom situations), high ratios between bacterial biomass and production and phytoplankton biomass and production were recorded while the lowest ratio was observed on the Dogger Bank where the spring bloom was initiated.
Table 4. Bacterial biomass (BB) and production (measured as ${ }^{3} \mathrm{H}$-thymidine $\left(B P_{1}\right)$ and ${ }^{3} \mathrm{H}$-leucine $\left(\mathrm{BP}_{1}\right)$ incorporation) expressed as a percentage of phytoplankton biomass (PB) and production (PP) in the 4 regions described in Fig. 11

\begin{tabular}{|c|c|c|c|c|}
\hline & \multicolumn{4}{|c|}{ Region } \\
\hline & Stns 20,22 ) & $\begin{array}{c}2 \\
\text { (Stns } 24-28 \text { ) }\end{array}$ & $\begin{array}{c}3 \\
(\text { Stns 30, 33) }\end{array}$ & $\begin{array}{c}4 \\
\text { (Stns } 84-88 \text { ) }\end{array}$ \\
\hline $\mathrm{BB} \times 100 / \mathrm{PB}$ & 24 & 142 & 40 & 66 \\
\hline $\mathrm{BP}_{\mathrm{t}} \times 100 / \mathrm{PP}$ & 26 & 78 & 62 & 48 \\
\hline $\mathrm{BP}_{\mathbf{1}} \times 100 / \mathrm{PP}$ & 13 & 55 & 43 & 33 \\
\hline
\end{tabular}


a

South of Dogger Bank

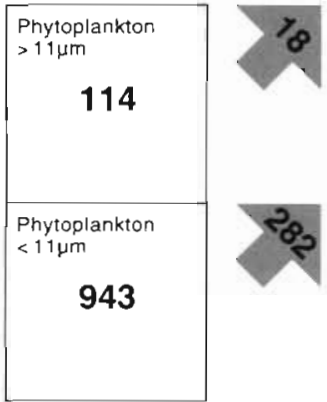

c

Northern edge of Dogger Bank
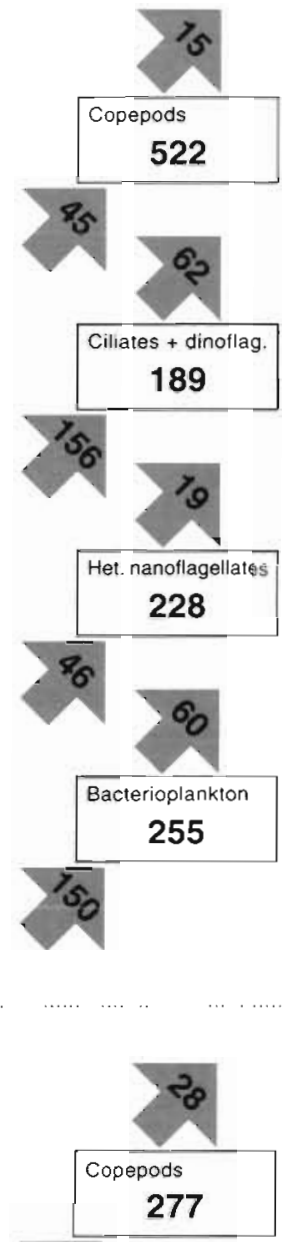

b

Dogger Bank
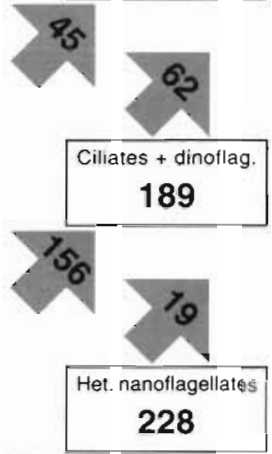

8

$\sigma_{0}$
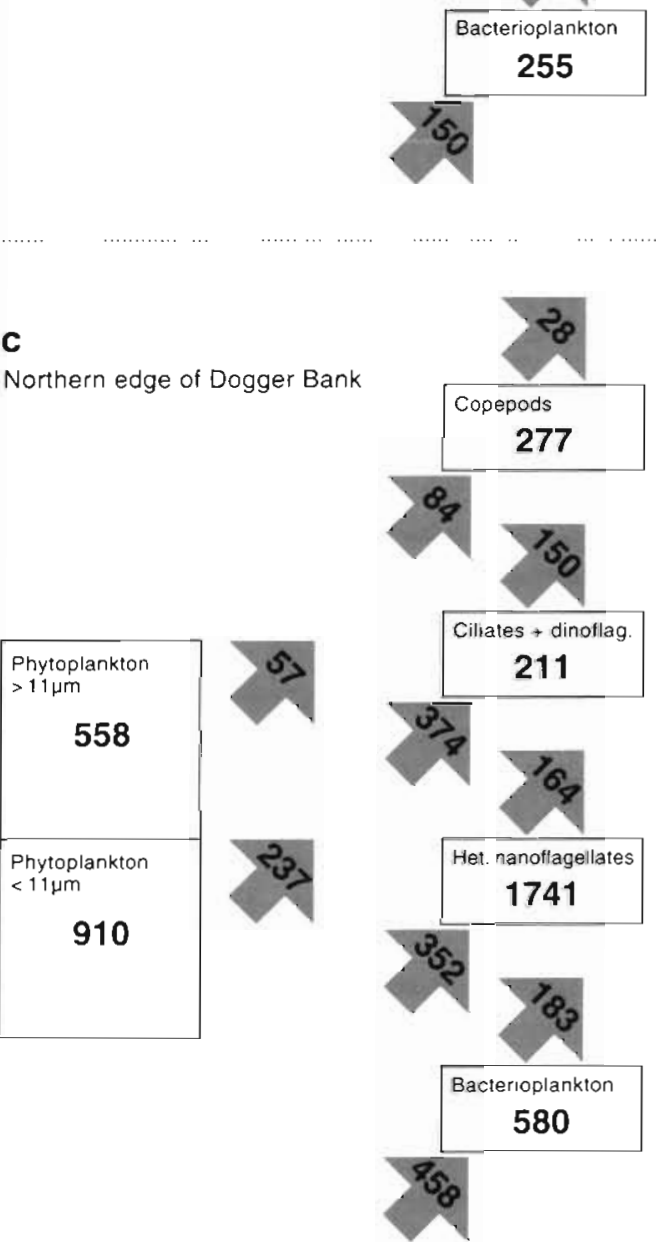

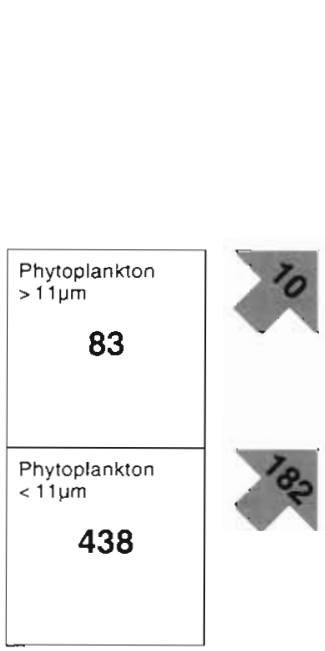

218
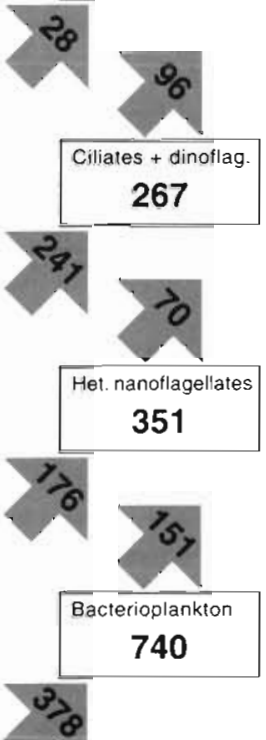

d

North of Dogger Bank

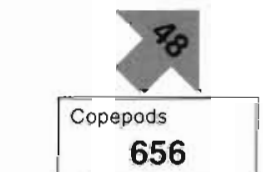

656
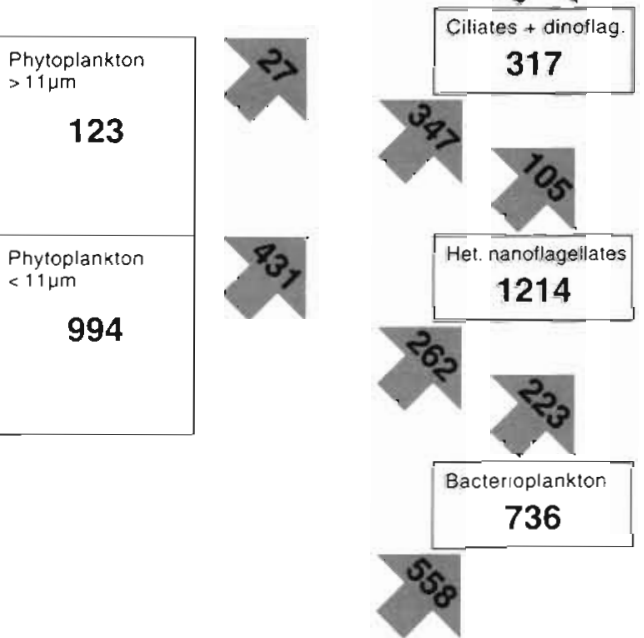

Fig. 11. Carbon flow budgets for the 4 regions (see text) investigated during the present study. (a) Region south of the Bank (b) Dogger Bank stations; (c) deep stations on the northern edge of the Bank; and (d) deep stations along Transect 2. Numbers inside

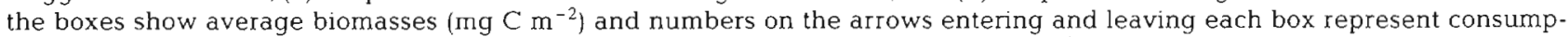
tion and production respectively $\left(\mathrm{mg} \mathrm{C} \mathrm{m}^{-2} \mathrm{~d}^{-1}\right)$ 
One possible explanation for the relative importance of the bacterioplankton on the Dogger Bank compared to the surrounding regions could be the large biomass of suspension feeding benthos found on the Bank (Duineveld et al. 1987). The shallow water on the Dogger Bank results in high mixing rates of the water column and, thus, frequent replacement of the water above the suspension-feeding benthos. The low retention efficiency of benthic suspension feeders for particles $<1 \mu \mathrm{m}$ (Jørgensen et al. 1984) and the release of dissolved organic nitrogen by the benthos (Doering 1989) may favour high bacterial biomass and production just above the bottom as seen in Fig. $5 \mathrm{c}$, d, e.

The daily grazing pressure exercised by the copepods on phytoplankton biomass and production in the sub-areas of our study ranged from 4 to $14 \% \mathrm{~d}^{-1}$ and 14 to $31 \% \mathrm{~d}^{-1}$, respectively (Fig. 11). The established carbon budgets suggest that approximately $30 \%$ of the phytoplankton production was grazed directly by copepods on the northern edge and north of the Dogger Bank, while only about $15 \%$ of the phytoplankton production was grazed directly by copepods on and south of the Bank. This higher grazing impact by copepods on phytoplankton at the stations north of the Bank may be related to the high biomass of Calanus finmarchicus north of Bank. The grazing impact is somewhat higher than has been reported for the central North Sea in May and June, 14 and $9 \%$ respectively (Baars \& Franz 1984). For the month of May, Tiselius (1988) reported a grazing pressure of about $50 \%$ at Calanus-dominated stations in the Skagerrak.

The size structure of the phytoplankton must, of course, also be taken into account when considering copepod grazing pressure. Roughly speaking, only the $>11 \mu \mathrm{m}$ fraction can be considered as potential prey items for copepods and the primary production in this phytoplankton fraction could only contribute from 19 to $68 \%$ of the copepod's daily carbon demand in this study. Thus, at this time, planktonic ciliates and other microzooplankton may have been of nutritional importance to the copepods.

We have estimated (from Table 5 and data given in Tiselius 1989) that the potential was present for copepods to clear the daily ciliate production in 3 of the 4 regions studied. In a study carried out in October-November in the Kattegat, Nielsen \& Kiørboe (1991) concluded that the ciliate population was probably limited by copepod predation but that ciliates contributed only insignificantly to the copepod diet $(6$ to $15 \%$ of the daily carbon demand). However, during the present investigation, the role of ciliates in the nutrition of copepods may have been much more important. Here, the estimated daily ciliate production was sufficient to meet the copepod carbon demand (Fig. 11).

Investigations of carbon cycling including the microbial loop and the importance of protozoans in the diet of marine zooplankton are limited. However, our data suggest that protozoans and, thus, the microbial loop may be an important link between the primary producers and the mesozooplankton during the stratified season in temperate waters where the primary producers (as observed during this investigation; Fig. 11) are dominated by pico- and nanoplankton.

\section{Importance of the Dogger Bank to the pelagic production of the North Sea}

The Dogger Bank is well known as a region of productive fisheries. However, the link between the geographic distribution of primary production in the North Sea and the location of the fisheries has never been established. Kiorboe et al. (1990) have suggested from data collected in the Skagerrak that it is, perhaps, wrong to expect a direct link between total primary production as it is routinely measured and the fishery. Instead, they suggest that new production (sensu Dugdale \& Goering 1967) should be related to the fishery.

During the study period described here, considerable primary production occurred in subsurface phytoplankton populations both to the north and the south of the Dogger Bank. Hydrographic characteristics, nutrient distribution and phytoplankton size distribution [using the argument that new production leads to a phytoplankton population composed of larger cells than regenerated production Cushing (1989), Kiørboe (in press)] all suggest that the production occurring in the subsurface phytoplankton layer immediately to the north of the Dogger Bank may comprise a greater component of new production than in the rest of the study region.

We argue that new production would be sustained by the intrusion of nutrient-rich bottom water along the pycnocline at the edge of the bank. Heat flux consider- 
ations (Becker 1981) suggest that thermal stratification of the North Sea to the north of the Dogger Bank can be expected from approximately May to September. Thus, assuming that there is always nutrient-rich bottom water to the north of the Dogger Bank and that our hypothesis concerning the occurrence of new production in the intrusion layer north of Dogger Bank is correct, the potential would seem to exist for new production to occur associated with the Bank edge throughout the summer months.

Richardson et al. (unpubl. data) have shown that primary production during the winter in the Dogger Bank region is higher (November to March) than for all other regions of the North Sea. Nielsen \& Richardson (1989) have demonstrated that the spring bloom was already underway over the Dogger Bank in February 1988. The FLEX experiment carried out in 1976 suggested that the spring bloom does not begin in the deeper northern North Sea (Fladen Ground) until mid-April (Williams \& Lindley 1980). Nielsen \& Richardson also demonstrated that the importance of the microbial loop was minimal in the region of the Dogger Bank during the spring bloom. This and the carbon budget considerations they presented suggest that the primary production occurring there during the winter can be considered as having a large component of 'new' production.

We suggest that the potential for the occurrence of a food chain based largely on 'new' production may be present during most, if not all, of the year in the region of the Dogger Bank. As it is 'new' production (sensu Dugdale \& Goering 1967) which sustains the short, classical food chain necessary to support a large fishery (e.g. Ryther 1969, Cushing 1989), we believe that this potential for 'new' production in the region of the Dogger Bank may explain this region's importance to the fishery

Acknowledgements. We thank Alice Christoffersen and Jack Melbye for technical assistance, Naja Vørs for identification of the flagellates, Thomas Kiorboe, Mike St. John, Peter Munk and 2 anonymous reviewers for critically reading the manuscript and the crew of RV 'Dana' for help with sampling.

\section{LITERATURE CITED}

Andrews, W. R. H., Hutchings, L. (1980). Upwelling in the southern Benguela Current. Prog. Oceanogr. 9: 1-81

Baars, M. A., Frantz, H. G. (1984). Grazing pressure of copepods on the phytoplankton stock of the central North Sea Neth. J. Sea. Res. 18: 120-142

Becker, G. A. (1981). Beiträge zur Hydrographie und Wärmebilanz der Nordsee. Dt. hydro. Z. 5(34): 1-262

Berggreen, U., Hansen, B., Kiørboe, T (1988). Food size spectra, ingestion and growth of the copepod Acartia tonsa implications for determination of copepod production. Mar. Biol. 99: 341-352
Billen, G., Joris, C., Meyer-Reil, L, Lindenbloom, H. (1990). Role of bacteria in the North sea ecosystem. Neth. J. Sea Res. 26(2-4): 265-293

Bjørnsen, P. K. (1986). Automatized determination of bacterioplankton biomass by image analysis. Appl. environ. Microbiol. 51. 1199-1204

Bjørnsen, P. K., Kaas, H., Kaas, H., Nielsen, T. G., Olesen, M., Richardson, K. (1993). Dynamics of a subsurface phytoplankton maximum in the Skagerrak. Mar. Ecol. Prog. Ser (in press)

Bjørnsen, P. K., Kuparinen, J. (1991). Growth and herbivory by heterotrophic dinoflagellates in the Southern Ocean, studies by microcosm experiments. Mar. Biol. 109: $397-405$

Bo Pedersen, F. (1993). The oceanographic and biological tidal cycle in shallow sea fronts in the North Sea and in the English Channel. Estuar. coast. Shelf Sci. (in press)

Cushing, D. H. (1973). Productivity of the North Sea. In Goldberg, E. D. (ed) North Sea Science. MIT Press, Cambridge, MA, p. 249-267

Cushing, D. H. (1989). A difference in structure between ecosystems in strongly stratified waters and in those that are only weakly stratified. J. Plankton Res. 11(1): 1-13

Dodge, J. D. (1985). Marine dinoflagellates of the British Isles. Her Majesty's Stationery Office, London

Doering, P. H. (1989). On the contribution of the benthos to pelagic production. J. mar. Res. 47: 371-383

Dugdale, R. C. Goering, J. J (1967). Uptake of new and regenerated forms of nitrogen in primary productivity. Limnol. Oceanogr. 12: 196-206

Duineveld, G. C. A., Künitzer, A., Heyman, R. P. (1987) Amphiura filiformis (Ophiuroidae: Echinodermata) in the North Sea. Distribution, present and former abundance and size composition. Neth. J. Sea Res. 21(4): $317-329$

Edler, L. (1979). Recommendations for marine biological studies in the Baltic Sea. The Baltic Marine Biologist Publications No. 5: 1-38

Fenchel, T. (1982). Ecology of heterotrophic microflagellates. IV. Quantitative occurrence and importance as bacterial consumers. Mar. Ecol. Prog. Ser. 9: 35-42

Fenchel, T. (1986). Protozoan filter feeding. Prog. Protistol. $1: 63-113$

Fenchel, T. (1988). Marine plankton food chains. A. Rev. ecol. Syst. 19: $19-38$

Fenchel, T., Finlay, B. (1983). Respiration rates in heterotrophic free-living protozoa. Microb. Ecol. 9: 99-122

Fuhrmann, J., Azam, F. (1980). Bacterioplankton secondary production estimates for coastal waters of British Colombia, Antarctica and California. Appl environ. Microbiol. 39(6): 1085-1095

Grasshoff, K. (1976). Methods of seawater analysis. Weinheim, New York

Haas, L. W. (1982). Improved epifluorescence microcopy for observing planktonic micro-organisms. Annls Inst. océanogr., Paris 58 (suppl.): 261-266

Hay, S. J., Kiørboe, T., Matthews, A. (1991). Zooplankton biomass and production in the North Sea during the Autumn Circulation Experiment, October 1987-March 1988. Cont. Shelf. Res. 11(12): 1453-1476

Hobbie, J. E., Daley, R. J., Jaspers, S (1977). Use of nuclepore fjlters for counting bacteria by epifluorescence. Appl. environ. Microbiol. 33: 1225-1228

Holligan, P. M., Harris, R. P., Newell, R. C., Harbour, D. S., Head, R. N., Linley, E. A. S., Lucas, M. I., Tranter, P. R. G., Weekley, C. M. (1984). Vertical distribution and partitioning of organic carbon in mixed, frontal and stratified 
waters of the English Channel. Mar. Ecol. Prog. Ser. 14: $111-127$

Hundahl, H., Holck, J. (1980). A new in situ fluorometer for detection of Rodamine B and chlorophyll. Report No. 42 , Inst. of Physical Oceanography, Univ. of Copenhagen, p. $145-154$

Jørgensen, C. B., Kiørboe, T., Møhlenberg, F., Rlisgård, H. U. (1984). Ciliary and mucus-net filter feeding, with special reference to fluid mechanical characteristics. Mar. Ecol. Prog. Ser. 15: 283-292

Kaas, H., Larsen, J., Mohlenberg, F., Richardson, K. (1991). The Chrysochromulina polylepis bloom in the Kattegat (Scandinavia) May-June 1988. Distribution, primary production and nutrient dynamics in the late stage of the bloom. Mar. Ecol. Prog. Ser. 79: 151-161

Kahl, A. (1932). Urtiere oder protozoa. I. Wimpertiere oder Ciliata (Infusoria). 3. Spirotricha. In: Dahl, F. (ed.) Die Tierwelt Deutschlands und der angrenzenden Meeresteile. Gustav Fishers Verlag, Jena

Kiørboe, T. (1993). Turbulence, phytoplankton cell size, and the structure of pelagic food webs. Adv. mar. Biol 29: in press

Kiørboe, T., Johansen, K. (1986). Studies of a larval herring (Clupea herrengus L.) patch in the Buchan area. IV. Zooplankton distribution and productivity in relation to hydrodynamic features. Dana 6: 37-51

Kiørboe, T., Kaas, H., Kruse, B., Møhlenberg, F., Tiselius, P., Ertebjerg, G. (1990). The structure of the pelagic food web in relation to water column structure in the Skagerrak. Mar. Ecol. Prog. Ser. 59: 19-32

Kiorboe, T., Mohlenberg, F., Riisgaard, H. U. (1985). In situ feeding rates of planktonic copepods: a comparison of four methods. J. exp. mar. Biol. Ecol. 88: 67-81

Kiørboe, T., Munk, P., Richardson, K., Christensen, V., Paulsen, H. (1988). Plankton dynamics and herring larval growth, drift and survival in a frontal area. Mar. Ecol. Prog. Ser. 44: 205-219

Kiorboe, T., Nielsen, T. G. (1990). Effect of wind stress on vertical water column structure, phytoplankton growth, and productivity of planktonic copepods. In: Barnes, M.,Gibson, R. N. (eds.) Trophic interactions in the marine environment. Proc. 24th Europ. Mar. Biol Symp. Aberdeen Univ. Press, Aberdeen, p 28-40

Kirchman, D., K'Nees, E., Hodson, R. (1985). Leucine incorporation and its potential as a measure of protein synthesis by bacteria in natural aquatic systems. Appl. environ. Microbiol. 49(3) : 599-607

Leegaard, C. (1915). Untersuchungen über einige Planktonciliaten des Meeres. Nyt. Mag. Naturvid. 53: 1-37

Lessard, E. J. (1991). The trophic roles of heterotrophic dinoflagellates in diverse marine environments. Mar Microb. Food Webs 5(1): 1-10

Lynn, D. J., Montagnes, D. J. S., Small, E. B. (1988). Taxonomic description of some conspicuous species in the family Strombidiidae (Ciliophora: Oligotrichida) from the Isles of Shoals, Gulf of Maine. J. mar. biol. Ass. U. K. 62(2): $252-259$

Nielsen, T. G., Kiørboe, T (1991). Effect of a storm event on the structure of the pelagic food web with special emphasis on planktonic ciliates. J. Plankton Res. 13(1): 35-51

Nielsen, T. G., Kiørboe, T., Bjørnsen, P. K. (1990). Effects of a Chrysochromulina polylepis subsurface bloom on the planktonic community. Mar. Ecol. Prog. Ser. 62: $21-35$

Nielsen, T. G., Richardson, K. (1989). Food chain structure of the North Sea plankton communities: seasonal variations in the structure of the microbial loop. Mar. Ecol. Prog. Ser. 56: 75-87

Parsons, T R., Takahasi, M., Hargrave, B. (1984). Biological oceanographic processes. Pergamon Press, New York

Peterson, W. T (1988). Rates of egg production by the copepod Calanus marshallae in the laboratory and in the sea off Oregon. Mar. Ecol. Prog. Ser. 47: 229-237

Peterson, W. T., Arcos, D. F., McManus, G. B., Dam, H. G., Johnson, T., Tiselius, P. (1988). The nearshore zone during coastal upwelling: daily variability and coupling between primary and secondary production off Chile. Prog. Oceanogr. 20: 3-40

Pierce, R. W., Turner, J. T. (1992). Ecology of planktonic ciliates in marine food webs. Rev. aquat. Sci. 6(2): 139-181

Pingree, R. D., Griffiths, D. K. (1978). Tidal fronts on the shelf seas around the British Isles. J. geophys. Sci. 83: 4615-4622

Pingree, R. D., Holligan, P. M., Mardsell, G. T. (1978). The effects of vertical stability on phytoplankton distribution in the summer on the northwest European shelf. Deep Sea Res. 25: 1011-1028

Richardson, K. (1985). Plankton distribution and activity in the North Sea/Skagerrak frontal area in April 1984. Mar. Ecol. Prog. Ser. 26: 233-244

Richardson, K., Christoffersen, A. (1991) Seasonal distribution and production of phytoplankton in the southern Kattegat. Mar. Ecol. Prog. Ser. 78: 217-227

Richardson, K., Heath, M. R., Pihl, N. J. (1986). Studies of a larval herring (Clupea harrengus L.) patch in the Buchan area. I. The distribution of larvae in relation to hydrographic features. Dana 6: $1-10$

Richardson, K., Lavin-Peregrina, M. F. Mitchelson, E. G., Simpson, J. H. (1985). Seasonal distribution of chlorophyll $a$ in relation to physical structure in the western Irish Sea. Oceanol. Acta 8: 77-86

Riegman, R., Malschaert, H., Colijn, F. (1990). Primary production of phytoplankton at a frontal zone located at the northern slope of the Dogger Bank (North Sea). Mar. Biol. 105: $329-336$

Riemann, B., Bjornsen, P. K., Newell, S., Fallon, R. (1987). Calculation of cell production of coastal marine bacteria based on measured incorporation of $\left({ }^{3} \mathrm{H}\right)$ thymidine. Limnol. Oceanogr. 32(2): 471-476

Ryther, J. H. (1969) Photosynthesis and fish production in the sea. Science 166: 72-76

Simon, M. Azam, F. (1989). Protein content and protein synthesis rates of planktonic marine bacteria. Mar. Ecol. Prog. Ser. 51: 201-213

Steele, J. H. (1974). The structure of marine ecosystems. Harvard University Press, Cambridge

Strickland, J. D., Parsons, T. R. (1972). A practical handbook of seawater analysis. Bull. Fish. Bd Can. 167

Tiselius, P (1988). Effects of diurnal feeding rhythms, species composition and vertical migration on the grazing impact of calanoid copepods in the Skagerrak and Kattegat. Ophelia 28: 215-230

Tiselius, P. (1989) Contribution of aloricate ciliates to the diet of Acartia clausi and Centropages hamatus in coastal water. Mar. Ecol. Prog. Ser. 56: 49-56

Van Duyl, F. C., Bak, R. P. M., Kop, A. J., Nieuwland, G. (1990). Bacteria, auto-and heterotrophic nanoflagellates and their relations in mixed,frontal and stratified waters of the North Sea. Neth. J. Sea. Res. 26(1):97-109

Williams, R., Lindley, J. A. (1980). Plankton of the Fladen Ground During FLEX 76 I. Spring development of the plankton community. Mar. Biol. 57: 73-78 